\title{
Penilaian Kinerja Rumah Sakit Umum Daerah Setelah Pelaksanaan Pola Pengelolaan Keuangan BLUD Pada Rumah Sakit Umum Daerah Liun Kendage Tahuna

\author{
VERA WATTY KORNELES ${ }^{1}$, GRACE. B. N ANGOI ${ }^{2}$, LINTJE KALANGI ${ }^{3}$
}

\author{
Program Studi Magister Akuntansi Fakultas Ekonomi dan Bisnis Universitas Sam Ratulangi \\ Email: verawattykorneles@gmail.com¹, gracebn@yahoo.com² ${ }^{2}$, lintjekalangi@gmail.com³
}

\begin{abstract}
The study aims to analyze the performance of the Liun Kendage Tahuna Regional Hospital after the implementation of the BLUD financial management pattern, analyze any obstacles that hamper hospital management after implementation of PPK-BLUD, and analyze efforts to resolve constraints in hospital management after the implementation of PPK-BLUD. This research was conducted at the Liun Kendage Tahuna Hospital. This is a qualitative research with a case study approach. Data were obtained by in-depth interviews, documentation studies and observations. The results showed that the financial management of RSUD Liun Kendage Tahuna was in accordance with Permendagri Number 79 Year 2018. Upon implementing PPK-BLUD, management of RSUD Liun Kendage Tahuna has included: 1). Financial aspects, 2). Service Aspects, 3). Regulation. The obstacles which have hampered the management of Liun Kendage Tahuna Hospital (after the implementation of PPK-BLUD for performance evaluation) are: 1). human resource constraints, 2). infrastructure constraints, and 3). government policy constraints. Efforts have been implied to resolve the existing constraints in the management of Liun Kendage Tahuna Hospital. Those efforts are that 1) Management staff at the hospital need to follow the training and technical guidance on BLUD management, 2)The hospital needs to add management staff in the financial department who have an Accounting background, and 3) Increase the number of medical personnel, both medical doctors and nurses. Furthermore, other effort is to propose an increase in the existing budget at the hospital. In order to support financial management, the hospital should propose using the SIA BLUD application system. The hospital needs to communicate with the local government regarding the mechanism of PPK-BLUD management to achieve a common perception of BLUD management between two parties.
\end{abstract}

Keywords: Performance Appraisal, RSUD, PPK-BLUD.

Abstrak. Penelitian ini bertujuan menganalisis kinerja RSUD Liun Kendage Tahuna setelah pelaksanaan pola pengelolaan keuangan BLUD, menganalisis kendala-kendala apa saja yang menghambat pengelolaan rumah sakit setelah pelaksanaan PPK-BLUD, serta menganalisis upaya untuk menyelesaikan kendala-kendala dalam pengelolaan rumah sakit setelah pelaksanaan PPK-BLUD. Penelitian ini dilakukan pada RSUD Liun Kendage Tahuna. Metode penelitian yang digunakan adalah metode penelitian kualitatif dengan pendekatan studi kasus. Data diperoleh peneliti melalui wawancara mendalam, studi dokumentasi dan observasi. Hasil penelitian menunjukkan bahwa pengelolaan keuangan RSUD Liun Kendage Tahuna sesuai dengan Permendagri Nomor 79 Tahun 2018. Pengelolaan RSUD Liun Kendage Tahuna, setelah pelaksanaan PPK-BLUD penilaian kinerjanya meliputi: 1). Aspek keuangan, 2). Aspek pelayanan 3). Peraturan. Kendala-kendala yang menghambat pengelolaan RSUD Liun Kendage Tahuna setelah pelaksanaan PPK-BLUD adalah kendala sumber daya manusia, kendala sarana prasarana, dan kendala kebijakan pemerintah. Upaya-upaya yang dilakukan untuk menyelesaian kendala-kendala yang ada dalam pengelolaan RSUD Liun Kendage Tahuna ialah staf pengelola yang ada pada rumah sakit perlu mengikuti Diklat dan Bimtek tentang pengelolaan BLUD. Pihak rumah sakit perlu menambah staf pengelola pada bagian keuangan yang mempunyai latar belakang pendidikan akuntansi, serta menambah jumlah tenaga medis baik dokter ahli maupun perawat. Selanjutnya mengusulkan penambahan anggaran yang ada pada rumah sakit dan untuk mendukung pengelolaan keuangan, pihak rumah sakit harus mengusulkan menggunaan sistem aplikasi SIA BLUD. Pihak rumah sakit mengupayakan komunikasi dengan pemerintah daerah terkait mekanisme pengelolaan PPKBLUD sehingga akan ada persamaan persepsi pengelolaan BLUD yang tercipta antara kedua pihak.

Kata Kunci: Penilaian Kinerja, RSUD, PPK-BLUD.

\section{Pendahuluan}

Paradigma baru pengelolaan keuangan negara sesuai dengan paket peraturan perundangundangan di bidang keuangan negara meliputi Undang- undang Nomor 17 Tahun 2003 tentang Keuangan Negara, Undang-undang Nomor 1 Tahun 2004 Tentang perbendaharaan negara, Peraturan Pemerintah 
Nomor 23 Tahun 2005 Tentang Pengelolaan Keuangan Badan Layanan Umum mengandung tiga kaidah manajemen keuangan negarga yaitu: orientasi pada hasil, profesionalitas, dan akuntabilitas- transparansi. Yang semuanya bertujuan untuk meningkatkan pelayanan publik oleh pemerintah. Dalam UndangUndang Nomor 1 Tahun 2004 tentang Perbendaharaan Negara pada pasal 68 dan 69 menyatakan bahwa instansi pemerintah yang tugas pokok dan fungsinya memberi pelayanan kepada masyarakat dapat menerapkan pola pengelolaan keuangan yang fleksibel dengan menonjolkan produktivitas, efisiensi, dan efektivitas.

Rumah Sakit Umum Daerah (RSUD) merupakan salah satu unit kerja pemerintah yang memberikan pelayanan langsung kepada masyarakat dalam bidang kesehatan, sehingga RSUD dapat menerapkan PPK BLUD. Sebagai salah satu unit kerja yang memberikan pelayanan publik, RSUD mempunyai peranan penting dalam peningkatan kesejahteraan masyarakat sehingga diharapkan dapat terus meningkatkan serta memberikan pelayanan yang terbaik, lebih efektif serta efisien, lebih ekonomis dan bisa menyentuh langsung kebutuhan dalam bidang kesehatan setiap masyarakat yang ada. Oleh karena hal itu, maka rumah sakit umum daerah diharapkan bisa menghadirkan sarana dan prasarana yang memadai untuk pelayanan kepada masyarakat.

Dalam pelaksanaan kegiatan rumah sakit umum daerah masih banyak dijumpai berbagai kendala dalam pengelolaannya, baik dari aspek manajemen maupun operasional. Hal ini sangat dipengaruhi oleh berbagai tuntutan dari lingkungan yang ada, antara lain rumah sakit dituntut untuk dapat memberikan pelayanan kesehatan yang bermutu dengan biaya pelayanan kesehatan yang terjangkau. Dipandang dari segmentasi kelompok masyarakat, secara umum rumah sakit pemerintah merupakan layanan jasa yang menyediakan untuk kalangan menengah ke bawah, sedangkan rumah sakit swasta melayani masyarakat kelas menengah ke atas. Biaya kesehatan cenderung terus meningkat, dan rumah sakit dituntut untuk secara mandiri mengatasi masalah tersebut. Peningkatan biaya kesehatan menyebabkan fenomena tersendiri bagi rumah sakit pemerintahan karena rumah sakit pemerintah memiliki segmen layanan kesehatan untuk kalangan menengah ke bawah.

Selain itu aspek dukungan pihak pemerintah sangat mempengaruhi pengelolaan rumah sakit, namun dalam pelaksanaannya dukungan pihak pemerintah dirasakan masih sangat kurang, hal ini dapat dilihat dari terbatasnya anggaran operasional yang disediakan bagi rumah sakit, aturan pengelolaan keuangan yang masih rumit yang berdampak pada alur birokrasi yang terlalu panjang dalam melakukan proses pencairan dana. Salah satu solusi yang tepat untuk mengatasi hal diatas adalah dengan penerapan Badan Layanan Umum (BLU). Dengan menerapkan PPK-BLUD maka RSUD dapat membuat perencanaan, serta mengelolah secara langsung setiap pendapatannya, dan bisa mengendalikan semua urusan internal dalam rumah sakit secara lebih fleksibel, efektif dan lebih efisien yang semuanya bertujuan untuk menghadirkan kualitas pelayanan publik yang lebih baik.

RSUD Liun Kendage Tahuna merupakan fasilitas kesehatan yang dimiliki oleh Kabupaten Kepulauan Sangihe, yang menjadi salah satu penunjang kesejahteraan masyarakat yang ada di Kabupaten Kepulauan Sangihe. RSUD Liun Kendage Tahuna telah memiliki izin operasional untuk menyelenggarakan pelayanan kesehatan di lingkungan RSUD Liun Kendage Tahuna berdasarkan Surat Keputusan Bupati Kepulauan Sangihe Nomor 36/503.445/2014 tahun 2014 tentang izin operasional rumah sakit pada Rumah Sakit Umum Daerah Liun Kendage Tahuna Kabupaten Kepulauan Sangihe. Dalam rangka memberikan pelayanan kesehatan yang baik, fleksibilitas dan keleluasaan mengelola sumber daya pelaksanaan tugas operasional dan pengelolaan keuangan yang bertujuan meningkatkan pelayanan kepada masyarakat menjadi lebih efektif dan efisien, maka sejak tanggal 23 Desember 2015 Rumah Sakit Umum Daerah Liun Kendage Tahuna telah menerapkan Pola Pengelolaan Keuangan Badan Layanan Umum Daerah (PPK-BLUD) berdasarkan keputusan Bupati Kepulauan Sangihe Nomor : 245/445 Tahun 2015 tanggal 23 Desember 2015 tentang Penerapan Pola Pengelolaan Keuangan Badan Layanan Umum Daerah pada Rumah Sakit Umum Daerah Liun Kendage Tahuna.

RSUD Liun Kendage Tahuna sebagai rumah sakit umum daerah yang telah berstatus badan layanan umum dan telah menerapkan pola pengelolaan keuangan BLUD dalam kurun waktu kurang lebih 4 tahun (Periode 2015-2018) masih banyak mengalami kendala yang mengakibatkan pelayanan yang diberikan pada masyarakat masih belum optimal. Hal ini didasari oleh hasil survei pendahuluan lewat 
pengamatan serta wawancara peneliti dengan beberapa narasumber yaitu kasubag keuangan, bagian pelayanan serta beberapa orang pasien pada RSUD Liun kendage Tahuna. Dari wawancara didapatkan beberapa hal antara lain bahwa pengelolaan rumah sakit masih belum optimal hal ini disebabkan beberapa kendala antara lain rumah sakit Liun Kendage Tahuna masih sangat bergantung pada pendanaan dari APBD karena pendapatan yang dimiliki dari jasa pelayanan kesehatan belum optimal, hal ini dikarenakan rumah sakit mempunyai pasien yang sebagian besar berasal dari kalangan menengah ke bawah, yang seluruhnya menggunakan BPJS. Dan dalam beberapa tahun ini pihak RSUD sering mengalami keterlambatan dalam penerimaan pembayaran klaim dari pihak BPJS hal ini menyebabkan jumlah piutang yang ada pada tahun 2019 ini mencapai 8,9 Miliar sehingga pihak RSUD masih sangat kesulitan dalam hal pendanaan dan membutuhkan dukungan dana dari pihak pemerintah daerah dalam APBD yang dipergunakan untuk menunjang pelayanan kesehatan.

Dalam pengelolaan keuangan masih mengalami kendala yaitu kurangnya pemahaman pengelola terkait pelaksanaan PPK-BLUD khususnya dalam hal penyusunan dan penyajian laporan keuangan, pada bagian keuangan RSUD hanya terdapat satu orang yang mempunyai latar belakang pendidikan akuntansi yaitu kasubag keuangan sedangkan yang lain mempunyai latar belakang pendidikan kesehatan, sehingga dalam hal pengelolaan keuangan masih belum optimal. Dalam penyusunan laporan keuangan BLUD masih belum menggunakan sistem aplikasi tetapi masih secara manual dengan menggunakan program microsoft excel. Belum adanya penetapan tarif oleh pihak RSUD sehingga masih menggunakan tarif umum yang berdasarkan Peraturan Daerah sedangkan salah satu bentuk fleksibilitas dari pelaksanaan PPK-BLUD ialah RSUD sudah bisa menentukan tarifnya sendiri secara langsung sesuai dengan Peraturan Pemerintah Nomor 74 Tahun 2012 Pasal 9.

Pada pemberian pelayanan pada masyarakat masih didapatkan beberapa pasien rawat jalan yang banyak mengeluh tentang pelayanan administrasi yang dianggap masih sulit bagi pasien, obat-obatan yang sering kali tidak tersedia pada apotek sehingga mengharuskan pasien harus mencari pada apotek diluar rumah sakit serta fasilitas sarana dan prasarana kesehatan yang masih harus dibenahi. Kondisi seperti ini sering kali membuat masyarakat merasa kurang nyaman dalam menerima pelayanan kesehatan.

RSUD Liun Kendage Tahuna sebagai rumah sakit umum daerah yang menerapkan PPK-BLUD telah diberikan fleksibilitas dan keleluasaan dalam mengelolah keuangan serta sumber daya pelaksanaan operasional rumah sakit, sehingga sangat diharapakan dapat terjadi peningkatan mutu dan kualitas dalam pengelolaan keuangan dan pelayanannya. Sebagaimana tujuan dari penerapan PPK-BLUD di RSUD Liun Kendage Tahuna adalah dapat menyediakan dan memberikan pelayanan kesehatan yang baik kepada masyarakat, lebih efektif dan efisien.

Penilaian kinerja instansi pemerintah daerah harus mencakup penilaian kinerja keuangan dan non-keuangan, sesuai dengan Peraturan Direktur Jenderal Perebendaharaan Kementerian Keuangan Nomor PER 54/PB/2013 tentang Pedoman penilaian kinerja satuan kerja badan layanan umum bidang kesehatan. Dimana penilaian kinerjanya terdiri atas penilaian pada 2 aspek yaitu aspek bidang keuangan meliputi rasio keuangan dan kepatuhan pengelolaan keuangan BLU serta aspek bidang pelayanan meliputi kualitas layanan dan mutu, manfaat kepada masyarakat.

Menurut Halacmi 2005 (dalam Hayat 2018: 51) pelaksanaan penilaian kinerja dapat meningkatkan efisiensi, efektifitas, penghematan dan produktivitas pada organisasi sektor publik. Penilaian kinerja ini sesuai dengan salah satu persyaratan administrasi pada saat BLUD dibentuk, yaitu kesanggupan RSUD untuk meningkatkan kinerja. Selain itu penilaian kinerja ini juga digunakan untuk mengetahui tingkat pencapaian tujuan organisasi yang telah ditetapkan pada awalnya, penilaian kinerja ini juga digunakan untuk mengetahui tingkat pencapaian tujuan organisasi yang telah ditetapkan pada awalnya. Dalam Pasal 127 Permendagri Nomor 61 Tahun 2007 diatur pula bahwa evaluasi dan penilaian kinerja dilakukan setiap tahun oleh kepala daerah dan/atau dewan pengawas terhadap aspek keuangan dan nonkeuangan.

Tujuan diadakannya penelitian ini adalah untuk: 1) Menganalisis kinerja RSUD Liun Kendage Tahuna setelah pelaksanaan PPK-BLUD, 2) Menganalisis kendala-kendala apa saja yang menghambat pengelolaan RSUD Liun Kendage Tahuna setelah pelaksanaan PKK-BLUD, 3) Menganalisis upaya 
untuk mengatasi kendala-kendala dalam pengelolaan RSUD Liun Kendage Tahuna setelah pelaksanaan PPK-BLUD.

\section{Model Analisis}

\section{Gambar 2.1 Model Analisis}

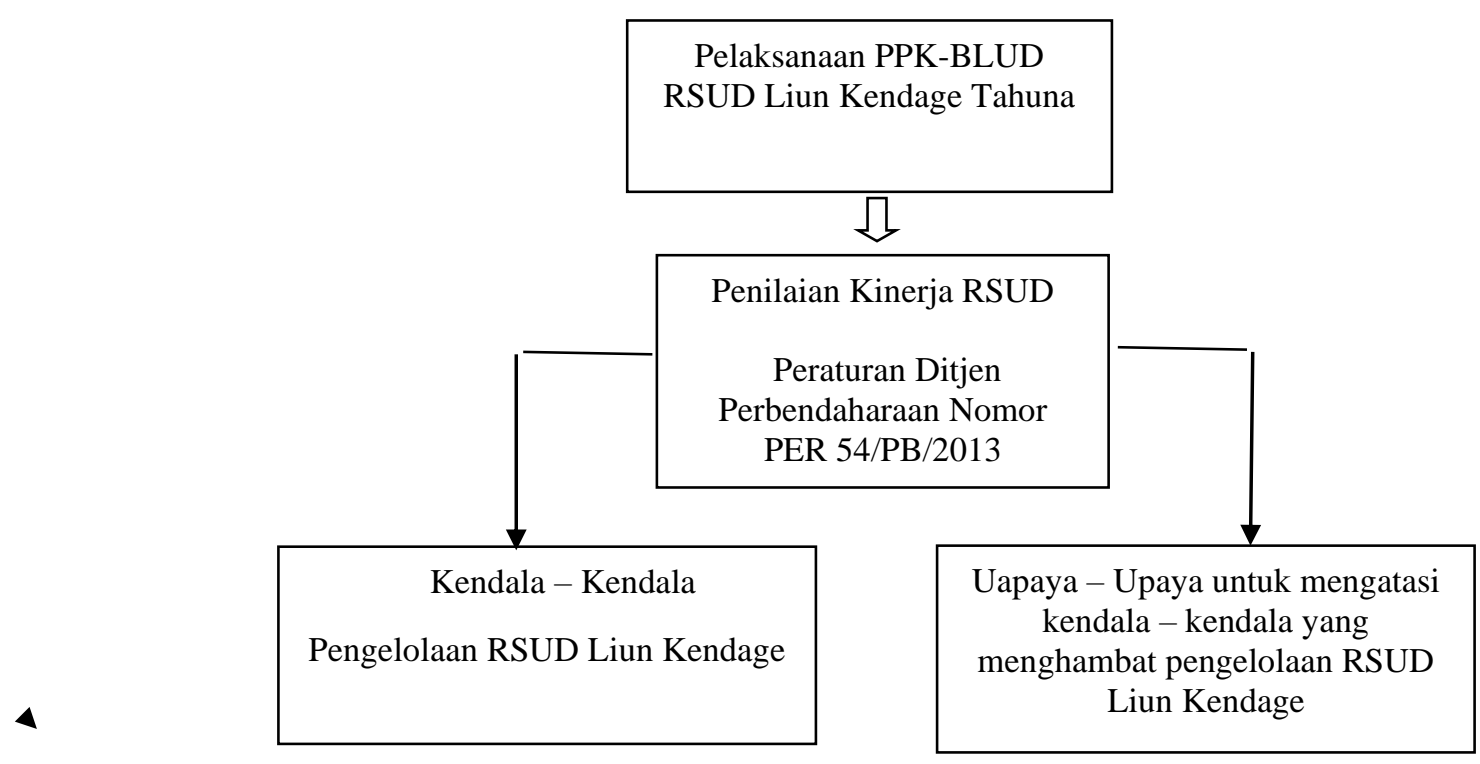

Sumber: Data Olahan (2019)

\section{Metode Penelitian}

Penelitian ini menggunakan metode penelitian kualitatif dengan pendekatan studi kasus. Dalam studi kasus, peneliti mencoba untuk meneliti tentang individu atau unit sosial tertentu secara mendalam dimana peneliti mencoba menemukan semua variabel penting yang melatarbelakangi timbulnya perkembagan variabel yang ada. Metode kualitatif dengan pendekatan studi kasus dipandang sesuai, karena dalam pendekatan ini, dilakukan studi mendalam terhadap unit sosial yang ada serta hasilnya dapat memberikan gambaran secara luas dan lebih terperinci.

Teknik pengumpulan data yang digunakan penulis dalam penelitian ini yaitu wawancara, observasi dan dokumentasi. Informan dalam penelitian ini terdiri dari Pimpinan, staf pengelola RSUD, serta pengguna jasa rumah sakit (pasien) yang semuanya berjumlah 15 orang. Dalam pengujian keabsahan data menggunakan uji kredibilitas, dimana menggunakan triangulasi sumber, triangulasi teknik dan triangulasi waktu.

\section{Analisis dan Pembahasan}

Untuk menjawab masalah pertama yaitu: "bagaimana kinerja RSUD Liun Kendage Tahuna setelah penerapan PPK-BLUD dilihat dari aspek keuangan dan non keuangan/pelayanan" ini dapat dinilai melalui pendekatan penilaian dalam Peraturan Ditjen Perbendaharaan Nomor PER 54/PB/2013 tentang Pedoman Penilaian Kinerja Satuan Keja Badan Layanan Umum Daerah Bidang Kesehatan dimana penilaian kinerja BLUD pada bidang kesehatan dinilai aspek keuangan yang meliputi rasio keuangan dan kepatuhan pengelolaan keuangan BLU, selanjutnya yang dinilai aspek pelayanan yang meliputi kualitas layanan dan mutu serta manfaat kepada masyarakat.

Untuk menjawab masalah kedua yaitu: "Kendala-kendala dalam pengelolaan RSUD Liun Kendage Tahuna setelah pelaksanaan PPK-BLUD” yang diperoleh dari wawancara langsung serta 
didukung observasi langsung di lapangan pada RSUD Liun Kendage Tahuna ditemukan 3 (tiga) tema yaitu sumber daya manusia, sarana dan prasarana, kebijakan pemerintah.

Untuk menjawab masalah ketiga yaitu: "Bagaimana upaya untuk mengatasi kendala dalam pengelolaan RSUD Liun Kendage Tahuna setelah pelaksanaan PPK-BLUD” yang diperoleh dari wawancara langsung serta didukung observasi langsung di lapangan pada RSUD Liun Kendage Tahuna ditemukan 3 (tiga) tema yaitu Upaya sumber daya manusia, upaya sarana dan prasarana, serta upaya kebijakan pemerintah.

\section{Kinerja Rumah Sakit Umum Daerah Liun Kendage Tahuna setelah penerapan PPK-BLUD.}

\section{Aspek Keuangan}

Tabel 4.1 SKOR PENILAIAN KINERJA RSUD LIUN KENDAGE TAHUNA ASPEK KEUANGAN

\begin{tabular}{|c|c|c|c|c|}
\hline NO & SUB ASPEK/INDIKATOR & SKOR & BOBOT & $\begin{array}{c}\% \\
\text { CAPAIAN }\end{array}$ \\
\hline \multirow[t]{10}{*}{1} & Rasio Keuangan & 19,00 & 5,75 & $30,26 \%$ \\
\hline & a. Rasio Kas (Cash Ratio) & 2,00 & 0,50 & $25,00 \%$ \\
\hline & b. Rasio Lancar (Current Ratio) & 2,50 & 0,50 & $20,00 \%$ \\
\hline & c. Periode Penagihan Piutang (Collection Period) & 2,00 & 0,50 & $25,00 \%$ \\
\hline & d. Perputaran Aset Tetap (Fixed Asset Turnover) & 2,00 & 2,00 & $100,00 \%$ \\
\hline & e. Imbalan atas Aset Tetap (Return on Fixed Asset) & 2,00 & 0,00 & $0,00 \%$ \\
\hline & f. Imbalan Ekuitas (Return on Equity) & 2,00 & 0,00 & $0,00 \%$ \\
\hline & g. Perputaran Persediaan (Inventory Turnover) & 2,00 & 0,50 & $25,00 \%$ \\
\hline & $\begin{array}{l}\text { h. Rasio Pendapatan Operasional terhadap Biaya } \\
\text { Operasional }\end{array}$ & 2,50 & 1,75 & $70,00 \%$ \\
\hline & i. Rasio Subsidi Biaya Pasien & 2,00 & 0,00 & $0,00 \%$ \\
\hline \multirow[t]{13}{*}{2} & Kepatuhan Pengelolaan Keuangan RSUD & 11 & 10,10 & $91,82 \%$ \\
\hline & a. Rencana Bisnis dan Anggaran (RBA) Definitif & 2,00 & 2,00 & $100,00 \%$ \\
\hline & b. Laporan Keuangan & 2,00 & 1,50 & $75,00 \%$ \\
\hline & c. Pengesahan Pendapatan dan Belanja BLU & 2,00 & 2,00 & $100,00 \%$ \\
\hline & d. Tarif Layanan & 1,00 & 1,00 & $100,00 \%$ \\
\hline & e. Sistem Akuntansi & 1,00 & 1,00 & $100,00 \%$ \\
\hline & f. Persetujuan Rekening & 0,50 & 0,50 & $100,00 \%$ \\
\hline & g. SOP Pengelolaan Kas & 0,50 & 0,50 & $100,00 \%$ \\
\hline & h. SOP Pengelolaa Piutang & 0,50 & 0,50 & $100,00 \%$ \\
\hline & i. SOP Pengelolaan Utang & 0,50 & 0,50 & $100,00 \%$ \\
\hline & j. SOP Pengadaan Barang dan Jasa & 0,50 & 0,30 & $60,00 \%$ \\
\hline & k. SOP Pengelolaan Barang Inventaris & 0,50 & 0,30 & $60,00 \%$ \\
\hline & Jumlah Aspek Keuangan & 30 & 15,85 & $52,83 \%$ \\
\hline
\end{tabular}




\section{Sumber: Bagian Keuangan RSUD}

Pengelolaan RSUD Liun Kendage Tahuna dilihat dari aspek keuangan berdasarkan pada tabel 4.1 yang diperoleh dari hasil perhitungan dan observasi pada bagian keuangan, dapat dijelaskan capaian secara keseluruhan masih belum optimal hal ini bisa dilihat pada skor 15,85 atau 52,83\% dari bobot 30 . Pengelolaan dari sisi aspek keuangan masih belum optimal, dimana aspek rasio keuangan yang memiliki nilai yang kurang yaitu 5,75 atau 30,26\% sedangkan aspek kepatuhan pengelolaan keuangan pelaksanaannya telah optimal dengan skor 10,10 atau $91,82 \%$. Rendahnya aspek rasio keuangan sebagian besar dikarenakan RSUD masih sangat bergantung pada APBD baik dari sisi pendapatan maupun belanja, jumlah piutang yang besar dari kegiatan operasional BLU BPJS.

\section{Aspek Pelayanan}

Tabel 4.2 SKOR PENILAIAN KINERJA RSUD LIUN KENDAGE TAHUNA ASPEK PELAYANAN

\begin{tabular}{|c|l|c|c|c|}
\hline NO & \multicolumn{1}{|c|}{ SUB ASPEK/INDIKATOR } & SKOR & BOBOT & $\begin{array}{c}\text { \% } \\
\text { CAPAIAN }\end{array}$ \\
\hline 1 & Kualitas Layanan & $\mathbf{3 0 , 5 0}$ & $\mathbf{3 5 , 0 0}$ & $\mathbf{8 7 , 1 4 \%}$ \\
\hline & a. Pertumbuhan Produktivitas & 16,50 & 18,00 & $91,67 \%$ \\
\hline & b. Efektifitas Pelayanan & 11,50 & 14,00 & $82,14 \%$ \\
\hline & c. Pertumbuhan Pembelajaran & 2,50 & 3,00 & $83,33 \%$ \\
\hline 2 & Mutu dan Manfaat Kepada Masyarakat & $\mathbf{2 9 , 0 0}$ & $\mathbf{3 5 , 0 0}$ & $\mathbf{8 2 , 8 5 \%}$ \\
\hline & a. Mutu Pelayanan & 12,50 & 14,00 & $89,29 \%$ \\
\hline & b. Mutu Klinik & 10,00 & 12,00 & $83,33 \%$ \\
\hline & c. Kepedulian Kepada Masyarakat & 3,00 & 4,00 & $75,00 \%$ \\
\hline & d. Kepuasan Pelanggan & 1,00 & 2,00 & $50,00 \%$ \\
\hline & e. Kepedulian Terhadap Lingkungan & 2,50 & 3,00 & $83,33 \%$ \\
\hline & Jumlah Aspek Pelayanan & $\mathbf{5 9 , 5 0}$ & $\mathbf{7 0 , 0 0}$ & $\mathbf{8 5 , 0 0 \%}$ \\
\hline
\end{tabular}

Sumber: Bagian Keuangan RSUD

Pengelolaan RSUD Liun Kendage Tahuna dilihat dari aspek Pelayanan berdasarkan pada tabel 4.2 yang diperoleh dari hasil perhitungan dan observasi dapat dijelaskan capaian secara keseluruhan sudah optimal hal ini bisa dilihat pada skor 59,50 atau 85,00\% dari bobot 70. Hal ini disebabkan karena setelah pelaksanaan PPK-BLUD di RSUD Liun Kendage Tahuna mengalami peningkatan dalam hal pelaksanaan pelayanan kesehatan pada masyarakat. Jumlah pasien yang datang ke rumah sakit terus meningkat dari tahun- tahun sebelumnya, ini menunjukan masyarakat masih percaya pada kualitas layanan yang diberikan rumah sakit.

\section{Ketaatan pada peraturan}

Peraturan merupakan salah satu aspek pendukung dalam pelaksanaan suatu kegiatan untuk mencapai tujuan organisasi, termasuk dalam proses pengelolaan operasional sampai dengan penyusunan 
laporan keuangan pada RSUD Liun Kendage Tahuna. Sesuai dengan teori implementasi kebijakan bahwa suatu kebijakan implementasinya dipengaruhi oleh beberapa faktor salah satunya adalah faktor peraturan, menurut Edison dkk (2016:41) dengan adanya peraturan karyawan dapat mengetahui tentang kewajiban yang harus dipenuhi, batasan yang harus dipatuhi dan hak-hak yang akan diterima.

Berdasarkan pengamatan dan informasi dari hasil wawancara bahwa pelaksanaan PPK-BLUD pada RSUD Liun Kendage Tahuna telah berpedoman pada peraturan yang berlaku yakni sesuai dengan Permendagri 61 Tahun 2007 tentang pedoman teknis pengelolaan keuangan Badan Layanan Umum Daerah, saat ini sudah mengikuti Permendagri 79 Tahun 2018 tentang Badan Layanan Umum Daerah, yang dalam pelaksanaannya dimulai dari pengusulan anggaran, pengelolaan keuangannya sampai dengan penyusunan laporan keauangan.

RSUD Liun Kendage Tahuna pada sisi non-keuangan dalam hal ini pelayanan yang diberikan, sudah sesuai dengan standar pelayanan minimal (SPM) bidang kesehatan yang ditetapkan oleh pemerintah daerah, pelayanan kesehatan yang ada berpedoman pada Peraturan Pemerintah Nomor 65 Tahun 2005 tentang pedoman penyusunan dan penerapan standar pelayanan minimal, Surat Keputusan Menteri Kesehatan nomor 1457 Tahun 2003 dan Keputusan Menteri Kesehatan Nomor 129 Tahun 2008 tentang standar pelayanan minimal rumah sakit dan Peraturan Bupati Nomor 22 Tahun 2015 tentang SPM RSUD Liun Kendage.

\section{Kendala-Kendala dalam Pengelolaan RSUD Liun Kendage Tahuna Setelah Pelaksanaan PPK- BLUD.}

Berdasarkan pengamatan dan wawancara yang dilakukan, di RSUD Liun Kendage Tahuna setelah melaksanakan PPK-BLUD didapatkan bahwa terjadi peningkatan pada pengelolaan rumah sakit baik dari sisi keuangan maupun non-keuangan dibandingkan dengan sebelum rumah sakit berstatus BLUD. Walaupun dalam pengelolaannya ada peningkatan, tapi masih terdapat kendala-kendala yang dihadapi pihak rumah sakit, sehingga membuat pengelolaan rumah sakit masih belum optimal yaitu sumber daya manusia, faktor sarana prasarana dan kebijakan pemerintah.

Berdasarkan analisis hasil penelitian dengan menggunakan teknik triangulasi, diketahui kendalakendala dalam pengelolaan RSUD Liun Kendage Tahuna dapat dikelompokkan ke dalam tema yang meliputi sumber daya manusia, sarana prasaarana dan kebijakan pemerintah.

\section{Kendala Sumber Daya Manusia}

Sumber daya manusia sangat penting dalam menentukan kelangsungan kegiatan suatu organisasi. Sumber daya manusia yang berkualitas akan menentukan keberhasilan organisasi dalam menyusun rencana, melaksanakan kegiatan operasional dan mengendalikan jalannya organisasi untuk mencapai tujuan yang telah ditetapkan.

Dalam teori yang dikemukakan oleh Edward III (1980:9) dikutip oleh Tahir (2014) bahwa Implementasi Kebijakan dipengaruhi oleh beberapa faktor yaitu salah satunya faktor sumber daya manusia. Keberhasilan implementasi kebijakan harus didukung oleh sumber daya dimana sumber daya ini berupa manusia yang memiliki kompetensi implementasi dan sumber daya finansial. Sumber daya manusia yang merupakan salah satu aspek penggerak dalam menjalankan suatu kebijakan. Suatu organisasi akan menuju pengoptimalan tujuan organisasinya jika dapat meningkatkan kinerja karyawan/pegawainya dengan memaksimalkan kemampuan dari pegawainya itu sendiri.

kendala yang dimiliki oleh pihak RSUD dalam pengelolaan rumah sakit yaitu sumber daya manusia, baik tenaga medis maupun non-medis yang ada pada rumah sakit. Selain itu RSUD Liun Kendage Tahuna juga masih memerlukan tambahan pegawai baik itu staf/pegawai pengelola keuangan maupun tenaga medis. Pada bidang keuangan rumah sakit memerlukan tambahan pegawai dengan latar belakang pendidikan akuntansi, karena saat ini rumah sakit hanya mempunyai 1 orang pegawai dengan latar belakang pendidikan akuntansi selebihnya pegawai dengan latarbelakang pendidikan kesehatan. Untuk pelayanan kesehatan RSUD Liun Kendage Tahuna memerlukan tambahan dokter ahli THT karena rumah sakit masih belum mempunyai dokter ahli THT, juga membutuhkan tambahan dokter spesialis 
patologi klinik, dokter spesialis radiologi dan dokter spesialis rehabilitasi medik serta juga membutuhkan tambahan tenaga perawat.

\section{Kendala Sarana Prasarana}

Keberadaan sarana dan prasarana (Infrastruktur) yang memadai sangat penting dalam peningkatan kinerja sebuah organisasi. Pada RSUD Liun Kendage Tahuna setelah PPK-BLUD dilaksanakan maka ada peningkatan pada infrastruktur yang dimiliki baik dari segi pengadaan maupun pemeliharaan sarana dan prasarana yang ada. Setelah rumah sakit berstatus BLUD maka banyak infrastruktur yang ditambah, dibenahi, serta pemeliharaan yang ada sudah cukup baik. Meskipun sudah terjadi peningkatan dalam sarana prasarana (infrastruktur) setelah dilaksanakanna PPK-BLUD, namun dalam pelaksanaanya tetap saja terdapat kendala-kendala dalam sarana prasarana yang menjadikan pengelolaan rumah sakit belum optimal. Kendala yang dihadapi pihak rumah sakit dalam upaya menghadirkan infrastruktur yang baik ialah anggaran rumah sakit yang terbatas.

Selanjutnya sarana pendukung keuangan pada rumah sakit, dalam pengelolaan sampai dengan pelaporan keuangan masih dilakukan secara manual yaitu dengan bantuan Microsoft Excel dan belum menggunakan aplikasi software seperti sistem informasi akuntansi (SIA-BLUD) yang dibuat oleh BPKP. Sehingga dalam pengelolaan dan penyusunan pelaporan keuangan rumah sakit sedikit mengalami kendala. Suatu organisasi sangat tergantung pada sistem informasi agar selalu dapat kompetitif, sistem akuntansi merupakan suatu alat yang sangat penting bagi manajemen dalam merencanakan dan mengendalikan kegiatan-kegiatan dalam suatu organisasi, yang digunakan sebagai alat komunikasi untuk keperluan manajemen dan pihak luar.

Sistem informasi yang dikelola dapat lebih baik dan bermanfaat apabila dalam proses pengelolaannya dapat memanfaatkan teknologi informasi, yang tentu saja akan memberikan banyak nilai tambah karena kelebihan yang dimiliki teknologi informasi, contohnya membuat proses manual berubah menjadi otomatis. Sistem informasi manual yang telah ada sebelumnya mulai dipadukan dan diintegrasikan dengan teknologi-teknologi pendukung. Hal ini tentu saja akan berpengaruh besar pada standar kinerja perusahaan secara keseluruhan (Mulyani, 2014:1).

\section{Kendala Kebijakan Pemerintah}

Dalam pelaksanaan pengelolaan rumah sakit setelah pelaksanaan PPK-BLUD, pihak rumah sakit harus mendapatkan dukungan dari berbagai pihak, dan dukungan yang paling besar yaitu dukungan dari pihak pemerintah. Salah satu kendala yang juga mempengaruhi pihak RSUD Liun Kendage Tahuna dalam pelaksanaan pengelolaan ialah kebijakan pemerintah daerah Kab. Kepl. Sangihe.

Menurut Edison dkk (2016: 38) Kebijakan (policy) adalah suatu bentuk lisan atau tulisan yang menjadi pedoman dan dasar rencana dalam pelaksanaan suatu pekerjaan yang memberi batas dan arah kepada seseorang atau kelompok untuk melaksanakannya. Kebijakan merupakan keputusan dari pimpinan tentang arah pedoman atau yang belum diatur, bukan untuk kegiatan yang berulang-ulang. Dalam pengelolaan rumah sakit setelah pelaksanaan PPK-BLUD, dukungan dari pihak pemerintah masih kurang dirasakan oleh rumah sakit.

Secara keseluruhan pelaksanaan pengelolaan rumah sakit setelah melaksanakan PPK-BLUD masih terkendala pada dukungan pihak pemerintah daerah yang dirasakan masih kurang bagi pelaksanaan pengelolaan rumah sakit, belum adanya pemahaman yang sama antara pihak rumah sakit dan pemerintah daerah terkait pengelolaan mekanisme BLUD. Dalam rangka peningkatan kinerja RSUD Liun Kendage Tahuna, maka sangat dibutuhkan dukungan pemerintah daerah secara penuh bagi rumah sakit walaupun saat ini telah berstatus BLUD tapi dukungan pemerintah daerah khususnya dari segi anggaran sangat diharapkan sehinnga dengan dukungan dari kebijakan pemerintah maka rumah sakit dapat meningkatkan kinerja yang ada. 


\section{Upaya-Upaya Dalam Mengatasi Kendala Pada Pengelolaan RSUD Liun Kendage Tahuna Setelah Pelaksanaan PPK-BLUD.}

Pada RSUD Liun Kendage Tahuna setelah melaksanakan PPK-BLUD terjadi peningkatan pada pengelolaan rumah sakit baik dari sisi keuangan maupun non-keuangan dibandingkan dengan sebelum rumah sakit berstatus BLUD. Walaupun dalam pengelolaannya ada peningkatan, tapi masih terdapat kendala - kendala yang dihadapi pihak rumah sakit sehingga membuat pengelolaan rumah sakit masih belum optimal, oleh karena itu diperlukan upaya-upaya yang harus dilakukan untuk mengatasi kendalakendala yang ada. Ketika upaya-upaya dilakukan untuk mengatasi kendala yang ada maka pelayanan kesehatan yang ada pada RSUD Liun Kendage Tahuna dapat dilakukan dengan optimal.

\section{Upaya Dalam Mengatasi Kendala Sumber Daya Manusia}

Dalam pengelolaan rumah sakit, khususnya dalam hal memberikan pelayanan terbaik bagi masyarakat, maka rumah sakit memerlukan sumber daya manusia (pegawai dan tenaga medis) yang memiliki kemampuan dan keterampilan dalam melaksanakan pekerjaannya.

Dalam teori yang dikemukakan oleh Edward III (1980:9) dikutip oleh Tahir (2014) bahwa Implementasi Kebijakan dipengaruhi oleh beberapa faktor yaitu salah satunya faktor sumber daya manusia. Keberhasilan implementasi kebijakan harus didukung oleh sumber daya dimana sumber daya ini berupa manusia yang memiliki kompetensi implementasi dan sumber daya finansial. Sumber daya manusia yang merupakan salah satu aspek penggerak dalam menjalankan suatu kebijakan. Suatu organisasi akan menuju pengoptimalan tujuan organisasinya jika dapat meningkatkan kinerja karyawan/pegawainya dengan memaksimalkan kemampuan dari pegawainya itu sendiri.

Upaya yang harus pihak RSUD Liun Kendage Tahuna lakukan ialah mengikutsertakan pegawai yang ada khususnya pihak pengelola pada pendidikan dan pelatihan (DIKLAT), dan bimbingan teknis terkait pengelolaan BLUD, serta melakukan studi banding ke rumah sakit yang telah lebih dahulu melaksanakan PPK-BLUD. Terkait jumlah tenaga kerja yang ada baik tenaga medis maupun non-medis pihak rumah sakit perlu untuk melakukan penambahan. Pada bidang keuangan khususnya perlu diupayakan penambahan pegawai yang berlatar belakang pendidikan akuntansi sehingga terkait pengelolaan dan pelaporan keuangan sudah tidak akan terkendala lagi. Selanjutnya pada tenaga Medis memerlukan tambahan perawat, dokter ahli THT, dokter spesialis patologi klinik, dokter spesialis radiologi serta dokter spesialis rehabilitasi medik.

\section{Upaya Dalam Mengatasi Kendala Sarana Prasarana}

Dalam pengelolaan rumah sakit dalam memberikan pelayanan terbaik bagi masyarakat, rumah sakit memerlukan dukungan sarana dan prasarana (infrastruktur dan teknologi) yang memadai.

Upaya yang harus pihak RSUD Liun Kendage Tahuna lakukan ialah dengan mengatur anggaran yang ada sesuai dengan tingkat kebutuhannya, untuk kebutuhan sarana dan prasarana baik pengadaan maupun pemeliharaan yang membutuhkan dana yang tidak terlalu besar dan harus segera dipenuhi dapat segera menggunakan dana BLUD, selanjutnta ketika ada kebutuhan mendasar rumah sakit ,yang harus segera dipenuhi tetapi anggaran yang ada tidak cukup masih dapat dilakukan pergeseran anggaran belanja, misalnya dari anggaran perjalanan dinas bisa digeser ke anggaran peralataan kesehatan, sedangkan untuk kebutuhan dengan jumlah dana yang besar yakni diatas Rp. 200.000.000,- harus segera dianggarkan dalam DAK. Terkait dengan pengelolaan keuangan, pihak rumah sakit harus segera mengusulkan untuk menggunakan sistem aplikasi SIA BLUD sehingga dalam pengelolaan keuangan akan lebih baik dan optimal.

\section{Upaya Dalam Mengatasi Kendala Kebijakan Pemerintah}

Dalam pengelolaan rumah sakit sangat dibutuhkan dukungan dari pihak pemerintah daerah terutama dalam hal kebijakan-kebijakan pemerintah yang mendukung proses pengelolaan rumah sakit.

Upaya yang harus pihak RSUD Liun Kendage Tahuna lakukan ialah dengan mengupayakan komunikasi, menurut Christhoper Hood dalam Parsons (2006:467) menyatakan bahwa harus ada komunikasi yang sempurna di dalam dan diantara organisasi. Komunikasi antara pihak pemerintah daerah 
dan rumah sakit terkait mekanisme pengelolaan PPK-BLUD sehingga akan ada persamaan persepsi pengelolaan BLUD yang tercipta antara kedua pihak. RSUD Liun Kendage dapat mengundang Tim ahli/pakar BLUD misalnya Tim pembinaan BLUD dari BPKP untuk bisa memberikan penjelasan terkait mekanisme pengelolaan BLUD kepada pihak rumah sakit dan pemerintah daerah. Selanjutnya pihak rumah sakit berupaya untuk mengusulkan penambahan anggaran bagi RSUD dalam APBD, dengan dukungan kebijakan anggaran dari pemerintah maka pengelolaan rumah sakit akan optimal.

\section{Kesimpulan}

Penilaian Kinerja RSUD Liun Kendage Tahuna berdasarkan atas Peraturan Ditjen Perbendaharaan Nomor PER 54/PB/2013 dilakukan pada dua aspek yaitu Aspek Keuangan dan Aspek Pelayanan yang pelaksanaannya di dukung dengan peraturan perundang - undangan. Pada aspek keuangan, yakni penilaian pengelolaan rumah sakit dilihat dari aspek rasio keuangan dan aspek kepatuhan pengelolaan keuangan. Pengelolaan dari sisi aspek keuangan masih belum optimal, dimana aspek rasio keuangan yang memiliki nilai yang kurang yaitu 5,75 atau 30,26\% sedangkan aspek kepatuhan pengelolaan keuangan pelaksanaannya telah optimal dengan skor 10,10 atau 91,82\%. Sedangkan Aspek Pelayanan, yakni penilaian pengelolaan dilihat dari aspek kualitas pelayanan dan aspek mutu serta manfaat kepada masyarakat. Aspek Pelayanan telah optimal dengan skor 59,50 atau 85,00\% dari bobot 70 .

Dalam pelaksanaan pengelolaan RSUD Liun Kendage Tahuna terdapat kendala- kendala, yaitu kendala sumber daya manusia, kendala sarana prasarana dan kendala kebijakan pemerintah. Sehingga, untuk meningkatkan pelayanan pada RSUD diperlukan upaya - upaya sebagai berikut: a). Upaya sumber daya manusia, Pihak rumah sakit perlu mengikutsertakan staf pengelola pada kegiatan pendidikan dan pelatihan (Diklat) serta bimbingan teknis tentang pengelolaan PPK- BLUD, menambah jumlah staf yang berlatar belakang pendidikan Akuntansi, menambah jumlah tenaga medis yaitu dokter ahli dan perawat. b). Upaya Sarana Prasarana, Upaya untuk mengatasi kendala Sarana prasarana dalam pengelolaan RSUD Liun Kendage Tahuna, ialah dengan mengatur anggaran yang ada sesuai dengan tingkat kebutuhannya, untuk kebutuhan sarana dan prasarana baik pengadaan maupun pemeliharaan yang membutuhkan dana yang tidak terlalu besar dan harus segera dipenuhi dapat segera menggunakan dana BLUD, terkait dengan pengelolaan keuangan, pihak rumah sakit harus segera mengusulkan untuk menggunakan sistem aplikasi SIA BLUD sehingga dalam pengelolaan keuangan akan lebih baik dan optimal. c). Upaya untuk mengatasi kendala Kebijakan Pemerintah dalam pengelolaan RSUD Liun Kendage Tahuna, ialah dengan mengupayakan komunikasi antara pihak pemerintah daerah dan rumah sakit terkait mekanisme pengelolaan PPK-BLUD sehingga akan ada persamaan persepsi pengelolaan BLUD yang tercipta antara kedua pihak.

\section{Saran}

Berdasarkan kesimpulan yang telah diuraikan sebelumnya, terdapat beberapa saran untuk menjadi perhatian demi perbaikan pengelolaan RSUD Liun Kendage Tahuna sehingga dapat meningkatkan kinerja yang ada antara lain:

1. Perlunya dukungan anggaran bagi pihak rumah sakit dalam APBD, sehingga rumah sakit dapat melaksanankan kegiatan pengelolaan secara maksimal, baik untuk pengadaan, pemeliharaan sarana dan prasarana, pengadaan obat-obatan, serta untuk aktivitas rumah sakit lainnya.

2. Pihak Pemerintah Daerah harus memberikan dukungan penuh pada pihak RSUD Liun Kendage Tahuna dalam pengelelolaan operasional rumah sakit, walaupun sudah berstatus BLUD tapi rumah sakit masih sangat membutuhkan dukungan dana dalam kegiatan operasionalnya. Pihak pemerintah daerah dapat membantu pihak rumah sakit dalam optimalisasi penyelesaaian tunggakan piutang BPJS yang selalu mengalami keterlambatan dalam pembayarannya kepada pihak RSUD.

3. Dalam meningkatkan produktivitas SDM, pihak rumah sakit harus menambah tenaga kerja pada bagian medis maupun non-medis. Pada tenaga non-medis harus ditambahkan staf/pegawai pengelola keuangan yang mempunyai latar belakang pendidikan akuntansi, sedangkan pada 
tenaga medis yang ada rumah sakit perlu menambah dokter spesialis THT, dokter spesialis patologi klinik, dokter spesialis radiologi dan dokter spesialis rehabilitasi medis.

4. Dalam pengelolaan keuangan dan penyusunan laporan keuangan, pihak rumah sakit sudah harus menggunakan aplikasi misalnya menggunakan aplikasi Sistem Informasi Akuntansi (SIABLUD). Dengan adanya dukungan aplikasi SIA-BLUD maka pengelolaan dan penyusunan pelaporan keuangan rumah sakit akan lebih baik.

5. Pihak Rumah sakit harus menganggarkan subsidi biaya pasien untuk masyarakat yang kurang mampu sehingga dapat membantu masyarakat untuk bisa mendapatkan pelayanan yang lebih baik.

\section{Daftar Pustaka}

Edison, Emron. Yohny Anwar \& Imas Komariyah. 2016. Manajemen Sumber Daya Manusia (Strategi dan perubahan dalam rangka meningkatkan kinerja pegawai dan organisasi). Bandung. Alfabeta.

Hayat. 2018. Kebijakan Publik. Malang: Intrans Publishing.

Kementerian Dalam Negeri. 2007. Peraturan Menteri Dalam Negeri Nomor 61 Tahun 2007 tentang Pedoman Teknis Pengelolaan Keuangan Badan Layanan Umum Daerah.

Kementerian Dalam Negeri. 2018. Peraturan Menteri Dalam Negeri Nomor 79 Tahun 2018 tentang Badan Layanan Umum Daerah.

Kementerian Keuangan 2013. Peraturan Direktorat Jenderal Perbendahraan Nomor PER 54/PB/2013, tentang Pedoman Penilaian Kinerja Satuan Kerja Badan Layanan Umum.

Kementerian Pendayagunaan Aparatur Negara. 2007. Peraturan Menteri Negara Pendayagunaan Aparatur Negara Nomor PER/09/M.PAN/5/2007 tentang Pedoman umum penetapan indikator kinerja utama di lingkungan instansi pemerintah.

Kementerian Pendayagunaan Aparatur Negara. 2015. Peraturan Menteri Negara Pendayagunaan Aparatur Negara Nomor 01 Tahun 2015 tentang Pedoman evaluasi kinerja penyelenggaraan pelayanan publik.

Kementerian Keuangan. 2011. Keputusan Meteri Keuangan Nomor 454/KMK.01/2011 tentang Pengelolaan kinerja di Lingkungan Kementerian Keuangan.

Keputusan Bupati Kepulauan Sangihe Nomor: 36/503. 445/2014 Tahun 2014 tentang Izin operasional Rumah Sakit pada Rumah Sakit Umum Liun Kendage Tahuna.2014.

Keputusan Bupati Kepulauan Sangihe Nomor: 245/445 Tahun 2015 tentang Penerapan Pola Pengelolaan Keuangan Badan Layanan Umum Daerah pada Rumah Sakit Umum Daerah Liun Kendage Tahuna.2015.

Mulyani, Sri. 2014. Sistem Informasi Akuntansi Edisi 2. Modul. ISBN 9789790116894. Universitas Terbuka.

Parsons, Wayne. 2006. Public Policy: Pengantar Teori dan Praktik Analisis Kebijakan. Jakarta. Kencana Prenada Media Group.

Peraturan Bupati Kabupaten Kepulauan Sangihe Nomor 05 Tahun 2016 Tentang Pembentukan RSUD Liun Kendage Tahuna menjadi Unit Pelaksanaan Teknis Dinas Kesehatan Daerah. 2016.

Peraturan Pemerintah Republik Indonesia Nomor 74 Tahun 2012, tentang Pengelolaan Keuangan Badan Layanan Umum.

Peraturan Pemerintah Republik Indonesia Nomor 08 Tahun 2006, tentang Pelaporan keuangan dan kinerja instansi pemerintah.

Peraturan Pemerintah Republik Indonesia Nomor 23 Tahun 2005, tentang Pengelolaan Keuangan Badan Layanan Umum.

Peraturan Pemerintah Republik Indonesia Nomor 58 Tahun 2005, tentang Pengelolaan Keuangan Daerah. Republik Indonesia. 2004.

Undang - Undang Nomor 1 Tahun 2004 tentang Perbendaharaan Negara.

Tahir, A. 2014. Kebijakan Publik \& Transparansi Peyelenggaraan Pemerintah Daerah. Bandung: CV. Alfabeta. 